\title{
Dopamine Inactivates Tryptophan Hydroxylase and Forms a Redox- Cycling Quinoprotein: Possible Endogenous Toxin to Serotonin Neurons
}

\author{
Donald M. Kuhn ${ }^{1,2}$ and Robert Arthur Jr. ${ }^{1}$ \\ ${ }^{1}$ Cellular and Clinical Neurobiology Program, Department of Psychiatry and Behavioral Neurosciences, and ${ }^{2}$ Center for \\ Molecular Medicine and Genetics, Wayne State University School of Medicine, Detroit, Michigan 48201
}

Exposure of tryptophan hydroxylase (TPH), the initial and ratelimiting enzyme in the biosynthesis of the neurotransmitter serotonin, to dopamine under mild oxidizing conditions (iron + $\mathrm{H}_{2} \mathrm{O}_{2}$ ) or in the presence of tyrosinase results in a concentration-dependent inactivation of the enzyme. Dopamine, iron, $\mathrm{H}_{2} \mathrm{O}_{2}$, or tyrosinase alone does not alter TPH activity. Similarly, $\mathrm{N}$-acetyldopamine oxidized with one equivalent of sodium periodate causes a concentration-dependent inactivation of TPH as well. TPH is protected from dopamine-induced inactivation by reduced glutathione, ascorbic acid, and dithiothreitol but not by the radical scavengers DMSO, mannitol, or superoxide dismutase. Parallel studies with $\left[{ }^{3} \mathrm{H}\right]$ dopamine reveal a high negative correlation between inhibition of catalysis and incorporation of tritium into the enzyme. Those reducing agents and antioxidants that protect TPH from inactivation are

The neurotransmitter dopamine (DA) can have quite divergent effects on the brain, especially when neurons are placed under the influence of certain pharmacological agents. On one hand, the reinforcing effects of many addictive drugs such as morphine, cocaine, and nicotine are thought to be mediated by drug-induced release of DA in the limbic forebrain (Pontieri et al., 1995; Koob and Nestler, 1997). On the other hand, DA plays an important role in the neurotoxic actions of methamphetamine and 3,4methylenedioxymethamphetamine (MDMA) on DA and serotonin (5-HT) neurons alike (Seiden and Sabol, 1996; Gibb et al., 1997). A common effect among the neurotoxic amphetamines is their ability to cause the inhibition of tryptophan hydroxylase (TPH) (Schmidt et al., 1986; Stone et al., 1986), the initial and rate-limiting enzyme in the biosynthesis of 5-HT (Jequier et al., 1967) and a phenotypic marker for 5-HT neurons. This property alone could have numerous secondary effects considering the wide variety of physiological functions that are mediated by 5-HT neurotransmission (Whitaker-Azmitia and Peroutka, 1990). Altered 5-HT neurotransmission is also thought to play a role in several psychiatric conditions, and evidence of diminished 5-HT function in human MDMA and methamphetamine users has been presented (Steele et al., 1994; Green et al., 1995).

\footnotetext{
Received March 5, 1998; revised June 8, 1998; accepted June 25, 1998.

This research was supported by the National Institute on Drug Abuse Grant DA10756 and by the Joe Young, Sr., Psychiatric Research Fund of the Department of Psychiatry and Behavioral Neurosciences. We thank Dr. Doyle Graham for his comments and advice on dopamine-based quinones.

Correspondence should be addressed to Dr. Donald M. Kuhn, Department of Psychiatry and Behavioral Neurosciences, Gordon H. Scott Hall, Room 2125, 540 East Canfield, Detroit, MI 48201.

Copyright (C) 1998 Society for Neuroscience $\quad 0270-6474 / 98 / 187111-07 \$ 05.00 / 0$
}

effective in preventing the labeling of TPH by $\left[{ }^{3} \mathrm{H}\right]$ dopamine. Acid hydrolysis and HPLC with electrochemical detection (HPLC-EC) analysis of inactivated TPH revealed the formation of cysteinyl-dopamine residues within the enzyme. Exposure of dopamine-modified TPH to redox-cycling staining after SDSPAGE confirmed the formation of a quinoprotein. These results indicate that dopamine-quinones covalently modify cysteinyl residues in $\mathrm{TPH}$, leading directly to the loss of catalytic activity, and establish that TPH could be a target for dopaminequinones in vivo after drugs (e.g., neurotoxic amphetamines) that cause dopamine-dependent inactivation of TPH. Redox cycling of a TPH-quinoprotein could also participate in the serotonin neuronal toxicity caused by these same drugs.

Key words: tryptophan hydroxylase; dopamine; quinones; neurotoxic amphetamines; quinoproteins; serotonin

Certain aspects of DA chemistry make it a strong candidate for an endogenous neurotoxicant. DA readily oxidizes nonenzymatically to corresponding quinones (Graham, 1978; Graham et al., 1978), and it is well known that quinones can modify proteins (Graham et al., 1978; Gieseg et al., 1993; Hastings and Zigmond, 1994; Hastings et al., 1996b; Terland et al., 1997) and DNA (Stokes et al., 1996). The metabolism of DA by monoamine oxidase also produces $\mathrm{H}_{2} \mathrm{O}_{2}$ (Maker et al., 1981; Cohen et al., 1997), and the generation of reactive oxygen species downstream of the peroxide, such as superoxide or hydroxyl radicals (Halliwell, 1992), could also underlie the damaging effects of DA in neural tissue. High concentrations of DA can inhibit DA (Berman et al., 1996; Berman and Hastings, 1997) and glutamate transporter function in vitro (Berman and Hastings, 1997) and cause toxic effects in brain or cultured neurons (Rosenberg, 1988; Filloux and Townsend, 1993; Hastings et al., 1996a; Hoyt et al., 1997; Lai and Yu, 1997). Studies of DA cellular toxicity have not yet identified a specific target protein or nucleotide in brain tissue. In view of the effect of the neurotoxic amphetamines on $\mathrm{TPH}$, and considering that DA has been implicated in the actions of these drugs in vivo, we hypothesized that TPH could be a target for DA-induced modification. Direct tests of this hypothesis are now possible via the use of a recombinant TPH that can be purified to homogeneity and used for in vitro mechanistic studies relevant to the neurotoxic amphetamines (Kuhn and Arthur, 1997b). We demonstrate here that DA-quinones inactivate $\mathrm{TPH}$, suggesting that this enzyme could be a target for DA-quinones in vivo under conditions that elevate DA release (neurotoxic amphetamines) and/or synthesis [L-3,4-dihydroxyphenylalanine (L- 
DOPA)] and that cause DA-dependent inhibition of TPH (Gibb et al., 1997).

\section{MATERIALS AND METHODS}

Materials. The following materials were obtained from Sigma (St. Louis, MO): DA, dithiothreitol (DTT), ferrous ammonium sulfate, glutathione (GSH), $N$-acetyldopamine ( $N$-acetyl-DA), GSH-agarose beads, tryptophan, $\mathrm{H}_{2} \mathrm{O}_{2}$, nitroblue tetrazolium (NBT), sodium periodate, mushroom tyrosinase, and prestained molecular weight standards. The glutathione $S$-transferase (GST)-fusion protein vector pGEX4T-2 and thrombin protease $(7500 \mathrm{U} / \mathrm{mg}$ ) were purchased from Pharmacia (Piscataway, NJ). T4 DNA ligase and restriction endonucleases were purchased from New England Biolabs (Beverly, MA). Catalase was a product of Boehringer Mannheim (Indianapolis, IN). Tetrahydrobiopterin was purchased from Dr. B. Schircks Laboratories (Jona, Switzerland). Isopropyl $\beta$-Dthiogalactopyranoside (IPTG) was obtained from Gold Biotechnologies (St. Louis, MO). BL-21 (Escherichia coli) cells were purchased from Invitrogen (Carlsbad, CA). [ $\left.{ }^{3} \mathrm{H}\right] \mathrm{DA} \quad\left(3,4-\left[7-{ }^{3} \mathrm{H}\right]\right.$ dihydroxyphenylethylamine; $24.1 \mathrm{Ci} / \mathrm{mmol}$ ) was obtained from NEN Life Science Products (Boston, MA). BioSpin 6 chromatography columns were obtained from Bio-Rad (Hercules, CA).

Cloning and expression of TPH. TPH was cloned and expressed as a GST-fusion protein as described previously (D'Sa et al., 1996b; Kuhn and Arthur, 1997a). A deletional mutant constituting the catalytic domain of TPH (amino acids 99-444) was expressed in BL-21 (E. coli) cells. This form of TPH retains the essential catalytic properties of the wild-type enzyme and has proved useful in mechanistic studies of the catalytic properties of the enzyme (D'Sa et al., 1996a; Kuhn and Arthur, 1997b; Kuhn et al., 1997). Bacteria transformed with the plasmid bearing the TPH cDNA were grown overnight at $37^{\circ} \mathrm{C}$ and induced with $0.1 \mathrm{~mm}$ IPTG for $2 \mathrm{hr}$ at $30^{\circ} \mathrm{C}$. Bacteria were washed with $10 \%$ glycerol and resuspended in 0.1 vol of $50 \mathrm{~mm}$ Tris- $\mathrm{HCl}, \mathrm{pH} 7.5$. After sonication and centrifugation $(40,000 \times g)$ to sediment insoluble material, the supernatants were adsorbed on GSH-agarose for $30 \mathrm{~min}$ at $4^{\circ} \mathrm{C}$. Affinity beads with immobilized TPH were washed three times with $50 \mathrm{vol}$ of $50 \mathrm{~mm}$ Tris- $\mathrm{HCl}, \mathrm{pH} 7.5$, at $4^{\circ} \mathrm{C}$ and were used immediately as previously described (D'Sa et al., 1996b; Kuhn and Arthur, 1997b). In some experiments (specified below), TPH was removed from the GST-fusion tag by digestion with thrombin protease (10 $\mathrm{U}$ of protease per mg of protein) at room temperature for $1 \mathrm{hr}$. The cleaved TPH protein was separated from the GSH-affinity beads by filtration through glass wool.

Treatment of TPH with dopamine. The TPH-fusion protein $(\sim 15 \mu \mathrm{g}$ of protein per tube) was treated with varying concentrations of DA (5-200 $\mu \mathrm{M})$ at $30^{\circ} \mathrm{C}$ for $15 \mathrm{~min}$ in a volume of $1 \mathrm{ml}$ while still bound to GSH-affinity beads. After removal of DA by three washes of $100 \mathrm{vol}$ of $0.05 \mathrm{~m}$ Tris-HCl, $\mathrm{pH} 7.5$, residual enzyme activity was determined. In some experiments, enzyme preparations were also incubated with iron (ferrous ammonium sulfate, $100 \mu \mathrm{M}$ ) and/or $\mathrm{H}_{2} \mathrm{O}_{2}(1 \mathrm{mM})$ in all possible combinations with DA under the same incubation conditions. DA, as a representative catecholamine [dihydroquinone $\left(\mathrm{QH}_{2}\right)$ ], can be oxidized to semiquinones ( $\mathrm{QHs}$ ) and quinones (Qs) by the following series of reactions (Graham, 1978; Klegaris et al., 1995):

$$
\begin{gathered}
\mathrm{QH}_{2}+\mathrm{OH}^{-} \rightleftharpoons \mathrm{QH}^{-}+\mathrm{H}_{2} \mathrm{O} ; \\
\mathrm{QH}^{-}+\mathrm{O}_{2} \rightarrow \mathrm{QH}+\mathrm{O}_{2}^{\cdot^{-}} ; \\
\mathrm{QH}+\mathrm{O}_{2} \rightleftharpoons \mathrm{Q}+\mathrm{O}_{2}^{--}+\mathrm{H}^{+} ; \\
\mathrm{Fe}^{2+}+\mathrm{H}_{2} \mathrm{O}_{2} \rightarrow \mathrm{Fe}^{3+}+\mathrm{OH}+\mathrm{OH}^{-} .
\end{gathered}
$$

The oxidation of DA at neutral $\mathrm{pH}$ (Eqs. 1-3) was facilitated by the Fenton reaction (Eq. 4). Because the oxidation of DA can produce a variety of quinones, two additional methods were used to study the effects of DA-derived quinones on TPH. First, $N$-acetyl-DA was oxidized with one equivalent of $\mathrm{NaIO}_{4}$ to form a more stable $o$-quinone (Graham, 1978; Graham et al., 1978), and this solution was added to TPH and incubated as described above. Second, DA was converted directly to its quinone with tyrosinase $(50 \mathrm{U} / \mathrm{ml})$. Agents being tested for the ability to protect against the DA effect on TPH were added before DA and remained present throughout the $15 \mathrm{~min}$ incubation period. When attempts were made to reverse the effects of DA on TPH (e.g., with GSH or DTT), the enzyme was first treated with DA (and other agents) and washed free of all reagents. GSH or DTT was added to the enzyme, and samples were incubated at $4^{\circ} \mathrm{C}$ for $30 \mathrm{~min}$. After three additional buffer washes, residual TPH activity was determined.

Assay of TPH catalytic activity. TPH activity was assayed by measuring the formation of 5-hydroxytryptophan from tryptophan as described previously (D'Sa et al., 1996a,b; Kuhn and Arthur, 1997b; Kuhn et al., 1997). TPH activity was assayed while the protein remained bound to the GSH-affinity beads because adsorption of the TPH-fusion protein to the beads does not interfere with the catalytic function of the enzyme. The levels of protein in all enzyme samples were measured with bead-bound preparations using the method of Bradford (1976). Controls contained the appropriate buffers, solvents, and beads unexposed to protein. The GSH-agarose beads did not cause the bovine serum albumin standard curve to depart from linearity.

Treatment of TPH with $\left[{ }^{3} H\right]$ dopamine. To test whether DA was binding to TPH, we incubated the purified enzyme with varying concentrations of $\left[{ }^{3} \mathrm{H}\right] \mathrm{DA}$ alone or under conditions that convert DA to a quinone (above). These studies used TPH that was cleaved from the GST-fusion tag by thrombin. Protein $(\sim 20 \mu \mathrm{g}$ per tube $)$ was incubated with $\left[{ }^{3} \mathrm{H}\right] \mathrm{DA}$ at $30^{\circ} \mathrm{C}$ for $15 \mathrm{~min}$ in the presence of $50 \mathrm{~mm}$ Tris- $\mathrm{HCl}, \mathrm{pH} 7.5$, in a volume of $200 \mu \mathrm{l}$, and reactions were terminated by the addition of $1 \mathrm{ml}$ of ice-cold $10 \%$ trichloroacetic acid (TCA). Samples were then incubated on ice for $10 \mathrm{~min}$, and acid-insoluble material was trapped on Whatman GF/B filter disks by vacuum filtration. The disks were washed with an additional $5 \mathrm{ml}$ of $10 \%$ TCA, and after drying, the amount of acidprecipitable tritium was assayed by liquid scintillation spectrometry.

Acid hydrolysis and HPLC with electrochemical detection analysis for cysteinyl-dopamine. TPH $(\sim 3.5 \mathrm{mg})$ cleaved from the GST-fusion tag with thrombin was exposed to L-DOPA $(200 \mu \mathrm{M}) \pm$ tyrosinase $(50 \mathrm{U} / \mathrm{ml})$ as described above. Hydrolysis and HPLC analysis for cysteinyl-DA was then performed as described previously (Kato et al., 1986; Hastings and Zigmond, 1994). Reactions were arrested with an equivalent volume of $10 \%$ TCA followed by incubation at $4^{\circ} \mathrm{C}$ for $2 \mathrm{hr}$. The resulting precipitates were collected by centrifugation and washed three times with $10 \mathrm{ml}$ of ice-cold 5\% TCA. The final pellet was suspended in $0.75 \mathrm{ml}$ of $6 \mathrm{M} \mathrm{HCl}$ containing 5\% thioglycolic acid, transferred to a hydrolysis vessel, and purged extensively with nitrogen before sealing. Protein samples were heated to $110^{\circ} \mathrm{C}$ for $16 \mathrm{hr}$ in a sand bath. Hydrolyzed samples were then mixed with $50 \mathrm{mg}$ of acid-washed alumina in the presence of $2.7 \mathrm{M}$ Tris-HCL, $\mathrm{pH} 8.6$, sodium bisulfite $(0.2 \mathrm{~mm})$, and EDTA $(1 \% \mathrm{w} / \mathrm{v})$ to extract catechol-modified amino acid residues. Samples were mixed with alumina for $10 \mathrm{~min}$ at room temperature and washed extensively with water. Catechols were eluted with $0.4 \mathrm{ml}$ of $0.4 \mathrm{M}$ perchloric acid. The eluate was analyzed for cysteinyl-DA by HPLC with electrochemical detection (HPLC-EC). The HPLC mobile phase ( $0.05 \mathrm{M}$ sodium citrate, $0.05 \mathrm{M} \mathrm{NaH}_{2} \mathrm{PO}_{4}, 200 \mu \mathrm{M}$ EDTA, $1.5 \mathrm{~mm}$ heptanesulfonic acid, and $14 \%$ methanol, $\mathrm{pH} 3.3$ ) was pumped at a flow rate of $0.7 \mathrm{ml} / \mathrm{min}$ through a Beckman $5 \mu \mathrm{m}-\mathrm{C} 18$ column, and samples were oxidized at a glassy carbon electrode set to a potential of $+0.75 \mathrm{~V}$ versus $\mathrm{Ag} / \mathrm{AgCl}$. The presence of cysteinyl-DA was confirmed by comparison of samples with cysteinyl-DA standards prepared as described by Rosengren et al. (1985). Just before injection onto the HPLC column, an internal standard containing 3-4 ng of free DA was added to samples and cysteinyl-DA standards.

SDS-PAGE and redox-cycling staining. TPH was treated with DA alone or under conditions that convert DA to a quinone (above) and then was exposed to SDS-PAGE (Laemmli, 1970). Gels were electroblotted to nitrocellulose membranes at $100 \mathrm{~V}$ for $2 \mathrm{hr}$ at $4^{\circ} \mathrm{C}$ in a buffer of $25 \mathrm{~mm}$ Tris-HCl, pH 8.3, containing $192 \mathrm{~mm}$ glycine and $20 \%$ (v/v) methanol. Quinoproteins were detected by staining blots with NBT $(0.24 \mathrm{~mm}$ in $2 \mathrm{M}$ potassium glycinate buffer, $\mathrm{pH}$ 10) as described by Paz et al. (1991). The blue-purple-stained quinoproteins were photographed, blots were then stained for total protein with Ponceau S (0.1\% in 5\% acetic acid), and red-stained protein bands were rephotographed.

\section{RESULTS}

\section{Effects of DA on TPH}

It is known that catechols can inhibit TPH enzyme activity via competitive interactions with protein-bound iron (Johansen et al., 1991; D’Sa et al., 1996a,b). However, preincubation of TPH with $\mathrm{DA}$ for $15 \mathrm{~min}$ at $30^{\circ} \mathrm{C}$, followed by removal of free DA, did not influence enzyme activity. If TPH was exposed to DA under mild oxidizing conditions (iron $+\mathrm{H}_{2} \mathrm{O}_{2}$ ), DA exerted quite significant effects on the enzyme. The results in Figure 1 show that DA 


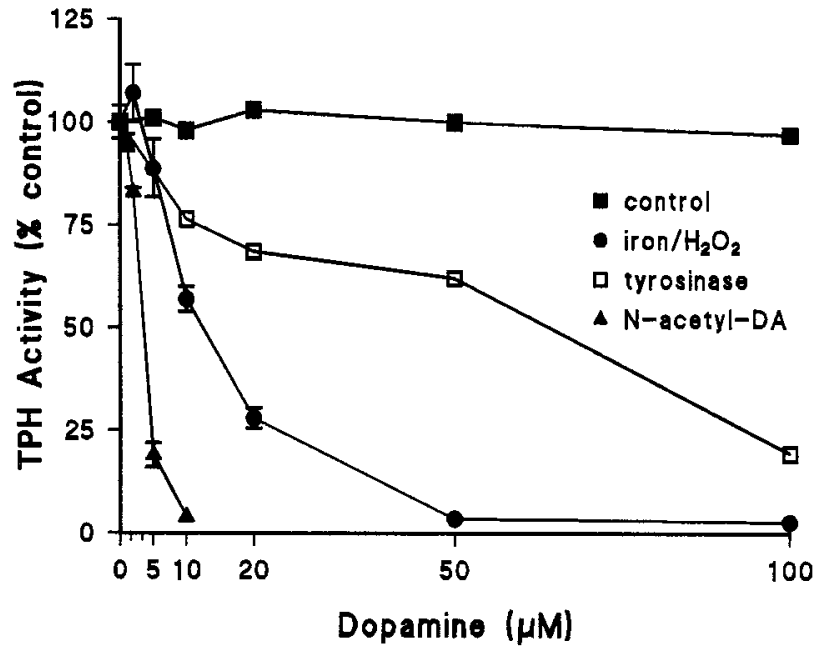

Figure 1. Effect of DA on TPH activity. TPH was exposed to the indicated concentrations of DA at $30^{\circ} \mathrm{C}$ in the presence of either $100 \mu \mathrm{M}$ ferrous ammonium sulfate $+1 \mathrm{mM} \mathrm{H}_{2} \mathrm{O}_{2}$ or tyrosinase at $50 \mathrm{U} / \mathrm{ml}$. When $\mathrm{N}$-acetyl-DA was used, it was first treated with a molar equivalent of $\mathrm{NaIO}_{4}$ and added immediately to the enzyme sample. Controls contained DA without other additions. Incubations with tyrosinase were performed for $30 \mathrm{~min}$, and all others were for $15 \mathrm{~min}$. After incubations, enzyme samples were washed free of all test reagents by washing the enzyme in 50 vol of $50 \mathrm{~mm}$ Tris- $\mathrm{HCl}, \mathrm{pH} 7.5$, at $4^{\circ} \mathrm{C}$, and the amount of TPH activity remaining was determined. Results represent the mean \pm SEM for four independent experiments performed in duplicate. The main effect of DA (or $N$-acetyl-DA) concentration was statistically significant $(p<0.001$, ANOVA) for each condition.

caused a concentration-dependent inactivation of TPH when incubated in the presence of $100 \mu \mathrm{M}$ iron and $1 \mathrm{mM} \mathrm{H}_{2} \mathrm{O}_{2}$. Concentrations of DA as low as $10 \mu \mathrm{M}$ resulted in partial inactivation of TPH (to $54 \%$ of the control level), and the enzyme was totally inhibited at concentrations of 50-100 $\mu \mathrm{M}$ DA in the presence of iron and $\mathrm{H}_{2} \mathrm{O}_{2}$. Exposure of TPH to iron or $\mathrm{H}_{2} \mathrm{O}_{2}$ individually was without effect. Similarly, coincubation of TPH and DA with either iron or $\mathrm{H}_{2} \mathrm{O}_{2}$ had no effect on the enzyme. The combination of iron $+\mathrm{H}_{2} \mathrm{O}_{2}$ caused a $10-15 \%$ reduction in TPH activity (data not shown). When tyrosinase was used to convert DA to its quinone in place of the Fenton reaction (Eq. 4), the results were similar, a concentration-dependent inactivation of TPH that was less potent than iron $+\mathrm{H}_{2} \mathrm{O}_{2}$. Finally, a more stable $o$-quinone $\left[N\right.$-acetyl-DA oxidized with $\mathrm{NaIO}_{4}(\mathrm{Graham}$, 1978)] was a very potent inhibitor of TPH. Concentrations of the $N$-acetyl-DA-derived $o$-quinone as low as $5 \mu \mathrm{M}$ caused a $75 \%$ reduction in TPH activity. Neither $N$-acetyl-DA nor $\mathrm{NaIO}_{4}$ alone modified TPH activity (data not shown). The concentration effects of all DA-quinones were statistically significant $(p<0.001$, ANOVA for each).

\section{Protection of TPH from DA-mediated inactivation}

Several reducing agents, antioxidants, and radical scavengers were tested for the ability to protect TPH from DA-induced inactivation. Figure 2 shows that GSH $(50 \mu \mathrm{M})$, ascorbic acid $(200 \mu \mathrm{M})$, and DTT $(500 \mu \mathrm{M})$ protected TPH from inactivation caused by any one of the DA-quinones. These same concentrations of GSH, ascorbic acid, and DTT were without effects on TPH in the absence of DA-quinones (data not shown). The overall effect of protectant was significant ( $p<0.001$, ANOVA), and individual comparisons of GSH, ascorbic acid, and DTT with their respective controls (for each quinone) were also significant $(p<0.01$,

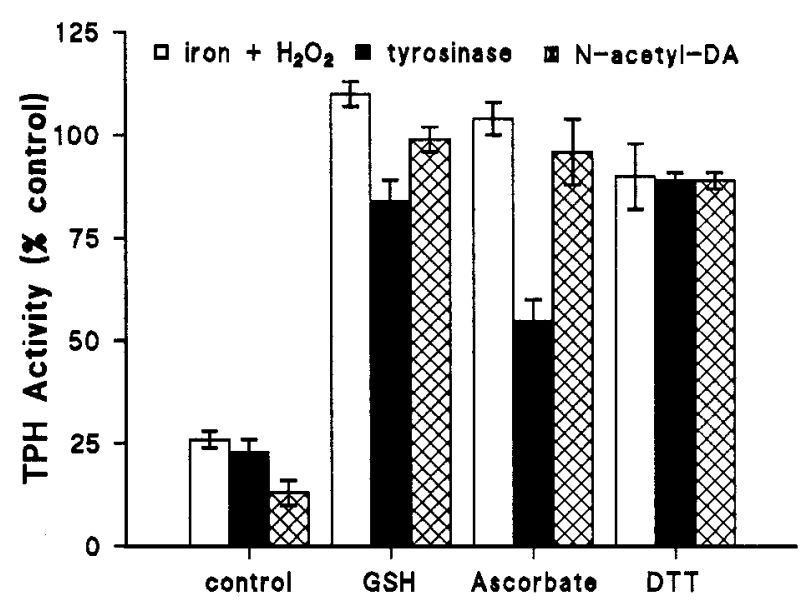

Figure 2. Protection of TPH from inactivation by DA. TPH was exposed to $20 \mu \mathrm{M} \mathrm{DA}$ at $30^{\circ} \mathrm{C}$ for $15 \mathrm{~min}$ in the presence of $100 \mu \mathrm{M}$ ferrous ammonium sulfate and $1 \mathrm{mM} \mathrm{H}_{2} \mathrm{O}_{2}$ or for $30 \mathrm{~min}$ in the presence of tyrosinase at $50 \mathrm{U} / \mathrm{ml}$ as described for Figure 1. $N$-acetyl-DA was oxidized with a molar equivalent of $\mathrm{NaIO}_{4}$, and the resulting solution was added to enzyme preparations at a concentration of $5 \mu \mathrm{M}$. GSH $(50 \mu \mathrm{M})$, ascorbic acid $(200 \mu \mathrm{M})$, or DTT $(500 \mu \mathrm{M})$ was added just before DA or $N$-acetylDA. The protectants were without effect on TPH in the absence of DA. Results represent the mean \pm SEM for four independent experiments performed in duplicate for each reagent. The overall effect of protectant was significant ( $p<0.001$, ANOVA), and the individual effects of GSH, ascorbic acid, and DTT were statistically different from their respective controls under all conditions (at least $p<0.01$, Bonferroni post hoc comparison).

Bonferroni post hoc comparison). Superoxide dismutase (250 $\mathrm{U} / \mathrm{ml})$, mannitol (10 $\mathrm{mm})$, and DMSO $(50 \mathrm{~mm})$ were ineffective in protecting the enzyme from inactivation caused by the DAquinones. Catalase $(0.13 \mathrm{U} / \mathrm{ml})$ did not protect against tyrosinase or $N$-acetyl-DA-induced inactivation (data not shown). Attempts were also made to recover TPH activity after inhibition had occurred. DTT (10-20 mM) or GSH (5-10 mM) was ineffective in reversing the inactivation caused by DA (data not shown).

\section{Binding of $\left[{ }^{3} \mathrm{H}\right] \mathrm{DA}$ to TPH}

TPH was treated with iron $+\mathrm{H}_{2} \mathrm{O}_{2}$, and $\left[{ }^{3} \mathrm{H}\right] \mathrm{DA}$ was included to determine whether protein-DA adducts were being formed. The results from these experiments are shown in Figure 3. It can be seen that incubation of TPH in the presence of $\left[{ }^{3} \mathrm{H}\right] \mathrm{DA}$ and iron plus $\mathrm{H}_{2} \mathrm{O}_{2}$ resulted in a concentration-dependent increase in the incorporation of tritium into acid-precipitated protein. This effect was statistically significant ( $p<0.001$, ANOVA). Results were the same if $\left[{ }^{3} \mathrm{H}\right] \mathrm{DA}$ was treated with tyrosinase in place of iron plus $\mathrm{H}_{2} \mathrm{O}_{2}$ (data not shown). At saturating concentrations of DA, the labeling of TPH with tritium was substoichiometric, resulting in the incorporation of $\sim 0.8$ moles of $\left[{ }^{3} \mathrm{H}\right] \mathrm{DA}$ per mole of TPH subunit. $\left[{ }^{3} \mathrm{H}\right] \mathrm{DA}$ did not label TPH in the absence of iron and $\mathrm{H}_{2} \mathrm{O}_{2}$. GSH $(50 \mu \mathrm{M})$ completely prevented tritium incorporation into TPH (Fig. 3), as did ascorbic acid and DTT at concentrations that protect TPH from inactivation by DA (data not shown). A plot of TPH inactivation and tritium incorporation into the enzyme versus the log concentration of DA is presented in Figure 4 and reveals a close relationship between these two dependent measures. Each separate interaction of DA with TPH was linear, and the two measures (inhibition of activity and tritium labeling) exhibited a high negative correlation $(r=-0.983)$. 


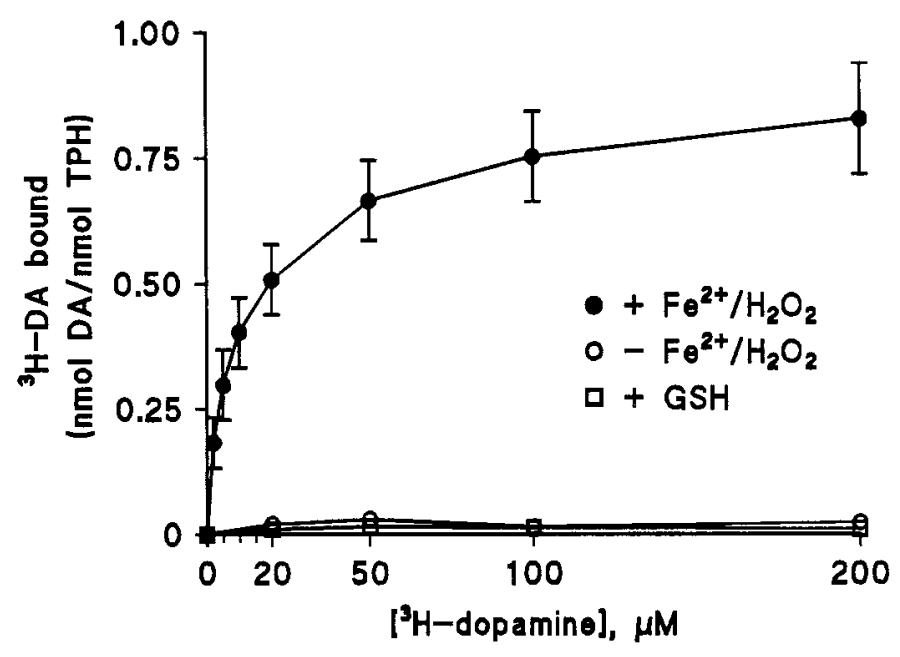

Figure 3. Binding of $\left[{ }^{3} \mathrm{H}\right] \mathrm{DA}$ to TPH. TPH was cleaved from the GST-fusion tag by incubation with thrombin protease as described in Materials and Methods. The purified, cleaved enzyme was incubated with the indicated concentrations of $\left[{ }^{3} \mathrm{H}\right] \mathrm{DA}$ at $30^{\circ} \mathrm{C}$ for $15 \mathrm{~min}$ in the presence of $100 \mu \mathrm{M}$ ferrous ammonium sulfate and $1 \mathrm{mM} \mathrm{H}_{2} \mathrm{O}_{2}$. Controls contained the same amount of isotope but omitted iron $+\mathrm{H}_{2} \mathrm{O}_{2}$. Reactions were stopped by the addition of $1 \mathrm{ml}$ of ice-cold $10 \%$ trichloroacetic acid. Precipitated protein was trapped on a Whatman GF/B filter by vacuum filtration. Filters were washed with $5 \mathrm{ml}$ of acid and dried, and tritium was quantified by liquid scintillation counting. Nonspecific binding of $\left[{ }^{3} \mathrm{H}\right] \mathrm{DA}$ was defined as the amount of label present in samples containing $2 \mathrm{~mm}$ DA (unlabeled) and was subtracted from all tubes. In some experiments, GSH $(50 \mu \mathrm{M})$, ascorbic acid $(200 \mu \mathrm{M})$, or DTT $(500 \mu \mathrm{M})$ was added to enzyme preparations just before $\left[{ }^{3} \mathrm{H}\right] \mathrm{DA}$. Only the results of GSH are plotted for the sake of clarity. The results represent the mean \pm SEM for four experiments run in duplicate. The effect of $\left[{ }^{3} \mathrm{H}\right] \mathrm{DA}$ binding to TPH was statistically significant $\left(p<0.001\right.$, ANOVA). $\left[{ }^{3} \mathrm{H}\right] \mathrm{DA}$ binding in the presence of GSH was significantly different from the $\left[{ }^{3} \mathrm{H}\right] \mathrm{DA}$-binding curve $(p<0.001$, ANOVA).

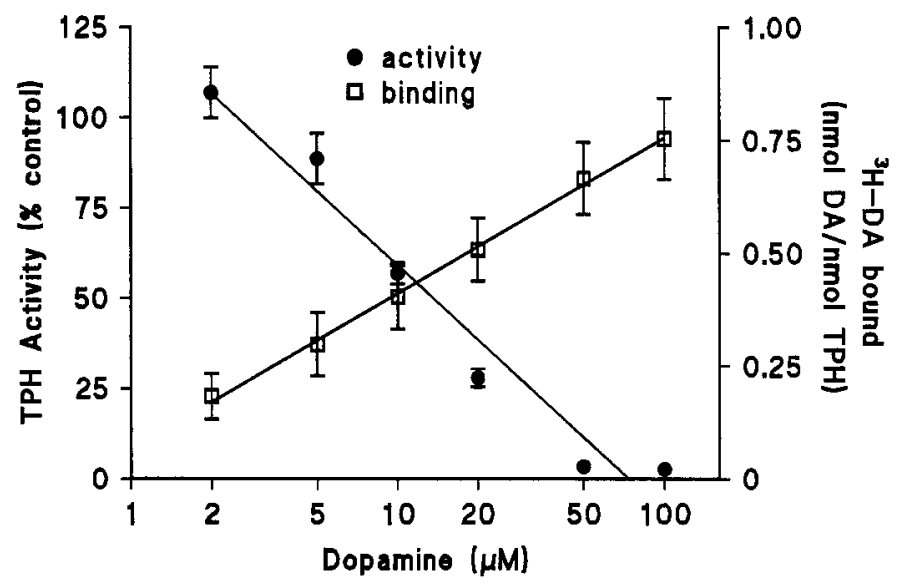

Figure 4. Relationship between ${ }^{3} \mathrm{H}$ incorporation and TPH activity. The results from $\left[{ }^{3} \mathrm{H}\right] \mathrm{DA}$ binding to TPH and the inactivation of enzyme activity by DA-quinones were plotted versus the log concentration of DA. Each relationship was linear, and the two measures exhibited a high negative correlation $(r=-0.983)$.

\section{Acid hydrolysis of TPH}

TPH (3.5 mg) was treated with DA $(200 \mu \mathrm{M})+$ tyrosinase $(50$ $\mathrm{U} / \mathrm{ml}$ ) and then exposed to acid hydrolysis and HPLC-EC in an attempt to establish the identity of the amino acid residue modified by DA-quinones. The results are presented in Figure 5. Standards of enzymatically generated cysteinyl-DA in Figure $5 \mathrm{~A}$
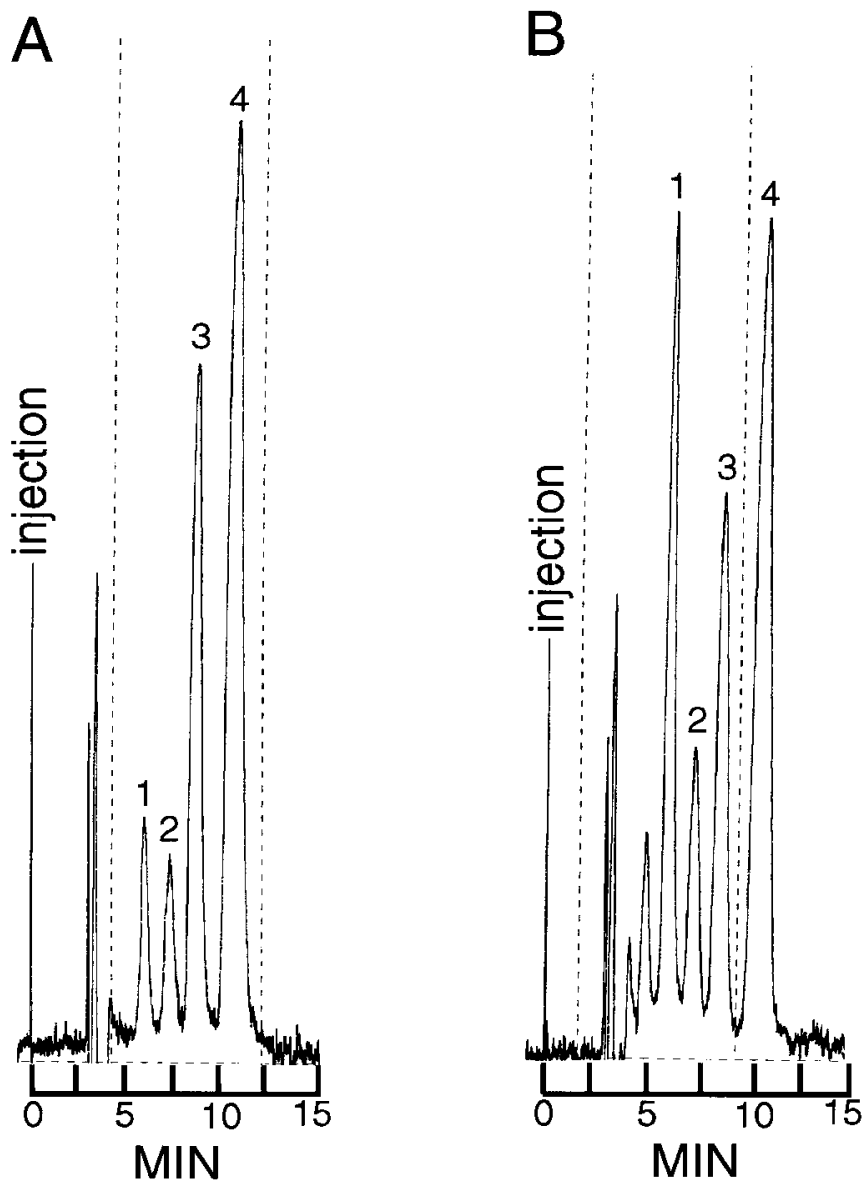

Figure 5. HPLC-EC analysis of DA-modified TPH. TPH $(3.5 \mathrm{mg})$ was treated with DA $(200 \mu \mathrm{M})+$ tyrosinase $(50 \mathrm{U} / \mathrm{ml})$ and exposed to acid hydrolysis and HPLC-EC analysis as described. Chromatographs represent standards of enzymatically generated cysteinyl-catechols $(A)$ and samples of DA-quinone-modified TPH $(B)$. The peaks in $A$ and $B$ are identified as follows: peak 1, injection spike, RT $=6.15 \mathrm{~min}$; peak 2, cysteinyl-DOPAC, RT = $7.6 \mathrm{~min}$; peak 3, internal standard of free DA added to each sample just before injection, RT $8.95 \mathrm{~min}$; and peak 4, cysteinyl-DA, $\mathrm{RT}=11.05 \mathrm{~min}$.

contain four major peaks and represent cysteinyl-DOPAC at 7.6 min, an internal standard of free DA at $8.95 \mathrm{~min}$, and cysteinyl-DA eluting with a retention time (RT) of $11.05 \mathrm{~min}$. An injection spike (present in all standard and sample injections) also eluted at $6.15 \mathrm{~min}$. These chromatographic results are consistent with previous studies investigating cysteinyl-DA (Rosengren et al., 1985; Kato et al., 1986; Hammond and Zigmond, 1994). Figure $5 B$ shows that the chromatographic profile of TPH treated with DA + tyrosinase contained the same peaks seen in the standard, with identical retention times. Peak 4, with the same retention time as cysteinyl-DA (11.05 min), establishes that TPH had been modified to contain cysteinyl-DA. The cysteinyl-DA peak is also clearly resolved from the DA internal standard, as shown in both chromatographic traces. If TPH was treated with DA or tyrosinase alone, the cysteinyl-DA peak was not observed (data not shown).

\section{Redox-cycling staining of TPH}

TPH was treated with DA $(100 \mu \mathrm{M})$ or under conditions that convert DA to a quinone and then was exposed to redox-cycling staining. The results in Figure $6 A$ demonstrate that DA alone did 

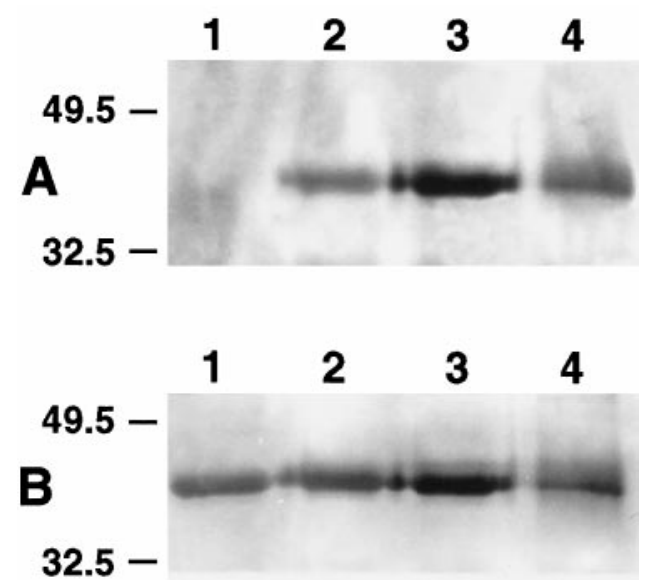

Figure 6. Redox-cycling staining of DA-modified TPH. TPH was purified and cleaved free of the GST-fusion tag as described in Materials and Methods. Enzyme $(8-10 \mu \mathrm{g})$ was then treated with $100 \mu \mathrm{M}$ DA alone (lane 1), with $100 \mu \mathrm{M}$ DA in the presence of $100 \mu \mathrm{M}$ ferrous ammonium sulfate $+1 \mathrm{mM} \mathrm{H}_{2} \mathrm{O}_{2}$ (lane 2), with $10 \mu \mathrm{M} \mathrm{N}$-acetyl-DA oxidized with $\mathrm{NaIO}_{4}$ (lane 3), or with $100 \mu \mathrm{M} \mathrm{DA}+50 \mathrm{U} / \mathrm{ml}$ tyrosinase (lane 4 ) for 15 min at $30^{\circ} \mathrm{C}$. SDS-stop solution was added to each tube, and samples were subjected to SDS-PAGE on $10 \%$ acrylamide gels. Proteins were transferred to nitrocellulose sheets, and blots were subjected to redox-cycling staining with $0.24 \mathrm{~mm} \mathrm{NBT}$ in $2 \mathrm{M}$ potassium glycinate, $\mathrm{pH} 10.0(A)$. After redox-cycling staining, blots were washed with water and restained for total protein with Ponceau $\mathrm{S}(B)$. The molecular weight standards indicated to the left of blots are prestained ovalbumin $(49.5 \mathrm{kDa})$ and prestained carbonic anhydride $(32.5 \mathrm{kDa})$. This experiment was repeated on five separate occasions with the same results.

not convert TPH to a quinoprotein (lane 1). However, incubation of TPH with DA + iron and $\mathrm{H}_{2} \mathrm{O}_{2}$ (lane 2), $N$-acetyl-DA $(10 \mu \mathrm{M})$ $+\mathrm{NaIO}_{4}$ (lane 3$)$, or DA + tyrosinase $(50 \mathrm{U} / \mathrm{ml}$; lane 4$)$ resulted in the formation of a quinoprotein. The quinoprotein has the same $M_{\mathrm{r}}$ as native TPH (i.e., $\sim 40,000$ ), consistent with the predicted $M_{\mathrm{r}}$ of the TPH catalytic core. We did not observe evidence that TPH cross-linked to higher $M_{\mathrm{r}}$ species after treatment with DA-quinones. Replacement of glycinate buffer with valinate abolished redox-cycling staining of TPH (data not shown). Figure $6 B$ is a Ponceau $\mathrm{S}$ stain of the same blot shown in Figure $6 A$ and confirms that all lanes contained approximately the same amount of protein.

\section{DISCUSSION}

TPH is presently shown to be inactivated after exposure to DA under specified conditions. All aspects of the data support the conclusion that DA-derived quinones are the agents mediating the inactivation. First, preincubation with DA alone had no effect on TPH activity. Second, conditions that prompt the conversion of DA to one of its quinones lead to significant reductions in TPH catalytic function. Because DA can be the source of numerous, different quinones (Graham, 1978; Graham et al., 1978; Kelgaris et al., 1995), we tested three representative ones in an attempt to establish the generality of their effects on TPH. DA was oxidized by iron $+\mathrm{H}_{2} \mathrm{O}_{2}$ to semiquinones and quinones as described in Equations 1-3. DA was also converted enzymatically to the aminochrome by tyrosinase, and finally, $N$-acetyl-DA was oxidized by $\mathrm{NaIO}_{4}$ to the more stable $o$-quinone (Graham, 1978; Graham et al., 1978). Each quinone caused significant inactivations of TPH. Third, GSH, DTT, and ascorbic acid protected TPH from inactivation by each of the DA-derived quinones. Antioxidants and reducing agents are well known to prevent quinone formation from DA or to reduce the DA-quinone back to DA (Graham, 1978; Graham et al., 1978; Hastings and Zigmond, 1994; Hastings et al., 1996b; Berman and Hastings, 1997). Quinones are electrondeficient compounds with high reactivity toward low molecular weight thiols, and the protectants could also exert their effects, in essence, by competing with protein sulfhydryls for the quinones (van Iwaarden et al., 1992). These same antioxidants and reductants also prevent DA-quinone-induced cellular (Hastings et al., 1996a,b; Hoyt et al., 1997; Terland et al., 1997) and DNA toxicity (Stokes et al., 1996).

The chemical properties of DA allow other possible avenues of influence on TPH in addition to quinones. The enzymatic metabolism of DA by monoamine oxidase yields $\mathrm{H}_{2} \mathrm{O}_{2}$ that could alter TPH (Kuhn and Arthur, 1996, 1997a,b). This possibility can be eliminated by the results that showed that scavengers of $\mathrm{H}_{2} \mathrm{O}_{2}$ (catalase), the hydroxyl radical (DMSO), or superoxide dismutase did not prevent the DA-mediated inactivation of TPH. Finally, catechol compounds such as DA and L-DOPA chelate ferric iron and can inhibit TPH by preventing iron redox during catalysis (Johansen et al., 1991; D'Sa et al., 1996a,b). The possibility that DA is inactivating TPH via chelation of iron also seems unlikely. Free DA was removed from the enzyme by extensive washing before assays for catalytic activity, and DA alone had no effect under the incubation conditions used here. DA also caused a covalent modification of TPH (see below) that is inconsistent with the competitive and reversible mechanism by which DA chelates TPH-bound iron (Johansen et al., 1991). The recombinant TPH used here is isolated as an apoenzyme, dependent on exogenous iron for expression of catalytic activity (D'Sa et al., 1996a,b; Kuhn and Arthur, 1996). Consequently, the enzyme contains little iron to serve as a target for DA binding.

TPH that had been cleaved from its GST-fusion tag was incubated with $\left[{ }^{3} \mathrm{H}\right] \mathrm{DA}$ under conditions similar to those used for catalytic studies to determine whether DA-TPH adducts were being formed. A concentration-dependent and saturable incorporation of tritium into the enzyme was observed under conditions that convert DA to a quinone. $\left[{ }^{3} \mathrm{H}\right] \mathrm{DA}$ alone did not label the enzyme. The labeling of TPH by $\left[{ }^{3} \mathrm{H}\right] \mathrm{DA}$-quinone was acidstable, suggesting a covalent modification of the protein. GSH, ascorbic acid, and DTT, at the same concentrations that protect TPH from DA-mediated inactivation, almost completely blocked labeling of TPH by $\left[{ }^{3} \mathrm{H}\right] \mathrm{DA}$. A plot of TPH inactivation and tritium incorporation into the enzyme against the logarithm of the DA concentration revealed a high negative correlation between these measures $(r=-0.983)$. Therefore, increasing incorporation of tritium into TPH is associated with decreasing catalytic function of the enzyme.

Quinones are highly reactive with nucleophilic groups including protein sulfhydryls. TPH is a very unstable enzyme, and alterations in its oxidation status can dramatically alter its catalytic function (Kuhn et al., 1980). In view of the covalent modification of the enzyme by DA-quinones and the close relationship between loss of activity and $\left[{ }^{3} \mathrm{H}\right] \mathrm{DA}$-quinone incorporation into $\mathrm{TPH}$, it was hypothesized that the quinone-induced inactivation was mediated by the alteration of cysteinyl residues. This hypothesis was tested by exposing DA-quinone-inactivated TPH to acid hydrolysis and HPLC-EC analysis. The results established that the inactivated enzyme contained cysteinyl-DA. Our results agree well with previous demonstrations that DA can lead to the formation of cysteinyl-catechols via reactive quinones (Hastings and Zigmond, 1994). They also strengthen the possibility that the toxic effects of intrastriatal DA injections (Hastings et al., 1996b) 
and the inhibition of DA (Berman et al., 1996) and glutamate transporter function (Berman and Hastings, 1997) by DA are mediated by DA-quinone attack on critical cysteinyl residues associated with these proteins.

TPH was exposed to redox-cycling staining after SDS-PAGE and was indeed converted to a quinoprotein by each DA-quinone under the same conditions that inactivate catalytic function. DA alone or conditions that do not diminish enzyme activity (e.g., iron, $\mathrm{H}_{2} \mathrm{O}_{2}, \mathrm{~N}$-acetyl-DA, $\mathrm{NaIO}_{4}$, or tyrosinase) did not result in redox-cycling staining. These results represent the first demonstration of this interesting post-translational modification in TPH. We do not yet know whether quino-TPH behaves as a "true" quinoprotein, an enzyme with a quinone-containing prosthetic group in its active site (Anthony, 1996; Klinman, 1996). This possibility is under investigation, but until evidence supporting a role for a quinone-prosthetic group function in modified TPH is gathered, quino-TPH is most conservatively referred to as an "artificial" quinoprotein (see Velez-Pardo et al., 1996).

The covalent modification of TPH by DA-quinones to form a redox-cycling quinoprotein represents a novel finding for this important brain enzyme and provokes interesting speculation with regard to 5-HT neurotoxicity. As a quinoprotein, TPH would undergo continuous redox cycling that could contribute to depletion of cellular energy stores and endogenous reductants. Indeed, redox-cycling proteins have been implicated in several forms of neurotoxicity (Brunmark and Cadenas, 1989; VelezPardo et al., 1996), and redox cycling is likely to be more pronounced with protein-bound quinones than with free quinones in solution (Paz et al., 1991). Cellular defense mechanisms that might be expected to protect against oxidative stress (e.g., GSH or ascorbate) could actually contribute to redox cycling of a quinoprotein (Paz et al., 1991; Gieseg et al., 1993; Velez-Pardo et al., 1996). Quinoproteins could also have effects that are longer-lived than those of reactive oxygen species, DA, or DA-quinones in solution (Hastings et al., 1996a,b; Shen and Dryhurst, 1996; Shen et al., 1997). TPH represents the first identified target for DAquinone attack, and as a phenotypic marker for 5-HT neurons, it would be in a position to have detrimental cellular effects in vivo via its redox-cycling properties.

The results from the present in vitro studies may be relevant for in vivo conditions known to cause deficits in 5-HT neurons. Substituted amphetamine drugs such as MDMA and methamphetamine inactivate TPH (Stone et al., 1989a,b; Fleckenstein et al., 1997) and lead to losses in 5-HT nerve endings (Seiden and Sabol, 1996; Gibb et al., 1997). The pattern of the effects of these drugs on the 5-HT neuronal system is consistent with the possibility that a DA-quinone could play a important role. First, the drug-induced 5-HT alterations are clearly dependent on DA (Gibb et al., 1997). Second, the in vivo inhibition of TPH by MDMA seems to involve the modification of critical cysteinyls in the enzyme (Stone et al., 1989a,b). Third, the 5-HT deficits caused by MDMA are prevented with injections of ascorbate or cysteine (Gudelsky, 1996).

A role for a TPH-quinoprotein in amphetamine-induced neurotoxicity is certainly plausible, as discussed above, but the specificity of DA-quinone modification of proteins is an important issue to address to define the scope of any role played by quinoproteins. TPH has 10 cysteinyl residues in its primary structure (Darmon et al., 1988) and would seem to be a good substrate for cysteinyl-based quinone attack. Very few proteins have been identified heretofore as catechol-induced quinoproteins. Exposure of crude brain extracts to high concentrations of DA results in the formation of just two redox-cycling quinoproteins (Liu et al., 1985; Velez-Pardo et al., 1996). The identity of these proteins has not been established beyond the characterization of their molecular weights of 45 and $56 \mathrm{kDa}$. These proteins were originally referred to as serotonin-binding proteins (Tamir and Huang, 1974), and the $56 \mathrm{kDa}$ protein is the same molecular weight as TPH. Studies of a very limited set of other catecholquinone-labeled proteins indicate that they vary widely in the extent to which they are labeled (Kato et al., 1996). Therefore, it does not seem that catechol-quinones nonspecifically label large numbers of proteins. The rather selective modification of proteins by DA-quinones would be consistent with the limited neuronal deficits caused by MDMA and methamphetamine.

GSH is probably the major determinant of cellular redox potential, and its intracellular concentration ranges from 1 to $10 \mathrm{~mm}$ (Hwang et al., 1992). Because GSH is so effective at protecting TPH from DA-quinone-induced inactivation in vitro, one must also question whether TPH could ever be modified by DAquinones in vivo. Reaction-rate kinetics provide a plausible basis for quinone modification of proteins, even in the presence of GSH. For example, Denu and Tanner (1998) have shown that protein phosphatases are inactivated by $\mathrm{H}_{2} \mathrm{O}_{2}$. Because the rate of inactivation is 100-fold faster than the rate of reduction (and reactivation) of the enzyme by GSH, inactivation takes place in the presence of physiological concentrations of reductants (Denu and Tanner, 1998). DA- and amphetamine-induced toxicity certainly occurs in vivo, despite the presence of GSH. It certainly seems possible that TPH could be at least one of the neuronal proteins targeted by drug-induced toxic mechanisms.

\section{REFERENCES}

Anthony C (1996) Quinoprotein-catalyzed reactions. Biochem J 320:697-711.

Berman SB, Hastings TG (1997) Inhibition of glutamate transport in synaptosomes by dopamine oxidation and reactive oxygen species. J Neurochem 69:1185-1195.

Berman SB, Zigmond MJ, Hastings TG (1996) Modification of dopamine transporter function: effect of reactive oxygen species and dopamine. J Neurochem 67:593-600.

Bradford MM (1976) A rapid and sensitive method for the quantitation of microgram quantities of protein utilizing the principle of protein-dye binding. Anal Biochem 72:248-254.

Brunmark A, Cadenas E (1989) Redox and addition chemistry of quinoid compounds and its biological implications. Free Radic Biol Med 7:435-477.

Cohen G, Farooqui R, Kesler N (1997) Parkinson disease: a new link between monoamine oxidase and mitochondrial electron flow. Proc Natl Acad Sci USA 94:4890-4894.

Darmon MC, Guibert B, Leviel V, Ehret M, Maitre M, Mallet J (1988) Sequence of two mRNAs encoding active rat tryptophan hydroxylase. $\mathrm{J}$ Neurochem 51:312-316.

Denu JM, Tanner KG (1998) Specific and reversible inactivation of protein tyrosine phosphatases by hydrogen peroxide: evidence for a sulfenic acid intermediate and implications for redox regulation. Biochemistry 37:5633-5642.

D'Sa C, Arthur Jr RE, States JC, Kuhn DM (1996a) Tryptophan hydroxylase: cloning and expression of the rat brain enzyme in mammalian cells. J Neurochem 67:900-906.

D'Sa C, Arthur Jr RE, Kuhn DM (1996b) Expression and deletion mutagenesis of tryptophan hydroxylase fusion proteins: delineation of the enzyme catalytic core. J Neurochem 67:917-926.

Filloux F, Townsend JT (1993) Pre- and postsynaptic neurotoxic effects of dopamine demonstrated by intrastriatal injection. Exp Neurol 119:79-88.

Fleckenstein AE, Beyeler ML, Jackson JC, Wilkins DG, Gibb JW, Hanson GR (1997) Methamphetamine-induced decrease in tryptophan hydroxylase activity: role of 5-hydroxytryptaminergic transporters. Eur J Pharmacol 324:179-186.

Gibb JW, Johnson M, Elayan I, Lim HK, Matsuda L, Hanson GR (1997) 
Neurotoxicity of amphetamines and their metabolites. NIDA Res Monogr 173:128-145.

Gieseg SP, Simpson JA, Charlton TS, Duncan MW, Dean RT (1993) Protein-bound 3,4-dihydroxyphenylalanine is a major reductant formed during hydroxyl radical damage to proteins. Biochemistry 32:4780-4786.

Graham DG (1978) Oxidative pathways for catecholamines in the genesis of neuromelanin and cytotoxic quinones. Mol Pharmacol 14:633-643.

Graham DG, Tiffany SM, Bell Jr WR, Gutknecht WF (1978) Autooxidation versus covalent binding of quinones as the mechanism of toxicity of dopamine, 6-hydroxydopamine and related compounds toward C1300 neuroblastoma cells in vitro. Mol Pharmacol 14:644-653.

Green AR, Cross AJ, Goodwin GM (1995) Review of the pharmacology and clinical pharmacology of 3,4-methylenedioxymethamphetamine (MDMA or "Ecstasy"). Psychopharmacology (Berl) 119:247-260.

Gudelsky GA (1996) Effect of ascorbate and cysteine on the 3,4methylenedioxymethamphetamine-induced depletion of brain serotonin. J Neural Transm 103:1397-1404.

Halliwell B (1992) Reactive oxygen species and the central nervous system. J Neurochem 59:1609-1623.

Hastings TG, Zigmond MJ (1994) Identification of catechol-protein conjugates in neostriatal slices incubated with $\left[{ }^{3} \mathrm{H}\right]$ dopamine: impact of ascorbic acid and glutathione. J Neurochem 63:1126-1132.

Hastings TG, Lewis DA, Zigmond MJ (1996a) Reactive dopamine metabolites and neurotoxicity. Adv Exp Med Biol 387:97-106.

Hastings TG, Lewis DA, Zigmond MJ (1996b) The role of oxidation in the neurotoxic effects of intrastriatal dopamine injections. Proc Natl Acad Sci USA 93:1956-1961.

Hoyt KR, Reynolds IJ, Hastings TG (1997) Mechanisms of dopamineinduced cell death in cultured rat forebrain neurons: interactions with and differences from glutamate-induced cell death. Exp Neurol 143:269-281.

Hwang C, Sinskey AJ, Lodish HF (1992) Oxidized redox state of glutathione in the endoplasmic reticulum. Science 257:1496-1502.

Jequier E, Lovenberg W, Sjoerdsma A (1967) Tryptophan hydroxylase inhibition: the mechanism by which $p$-chlorophenylalanine depletes rat brain serotonin. Mol Pharmacol 3:274-278.

Johansen PA, Wolf WA, Kuhn DM (1991) Inhibition of tryptophan hydroxylase by benserazide and other catechols. Biochem Pharmacol 41:625-628.

Kato T, Ito S, Fujita K (1986) Tyrosinase-catalyzed binding of 3,4dihydroxyphenylalanine with proteins through the sulfhydryl group. Biochim Biophys Acta 881:415-421.

Klegaris A, Korkina LG, Greenfield SA (1995) Autooxidation of dopamine: a comparison of luminescent and spectrophotometric detection in basic solutions. Free Radic Biol Med 18:215-222.

Klinman JP (1996) New quinocofactors in eukaryotes. J Biol Chem 271:27189-27192.

Koob GF, Nestler EJ (1997) The neurobiology of drug addiction. J Neuropsych Clin Neurosci 9:482-497.

Kuhn DM, Arthur Jr RE (1996) Inactivation of brain tryptophan hydroxylase by nitric oxide. J Neurochem 67:1072-1077.

Kuhn DM, Arthur Jr RE (1997a) Inactivation of tryptophan hydroxylase by nitric oxide: enhancement by tetrahydrobiopterin. J Neurochem 68:1495-1502.

Kuhn DM, Arthur Jr RE (1997b) Molecular mechanism of the inactivation of tryptophan hydroxylase by nitric oxide: attack on critical sulfhydryls that spare the enzyme iron center. J Neurosci 17:7245-7251.

Kuhn DM, Ruskin B, Lovenberg W (1980) Tryptophan hydroxylase: the role of oxygen, iron, and sulfhydryl groups as determinants of stability and catalytic activity. J Biol Chem 255:4137-4143.

Kuhn DM, Arthur Jr RE, States JC (1997) Phosphorylation and activation of brain tryptophan hydroxylase: identification of serine-58 as a substrate site for protein kinase A. J Neurochem 68:2220-2223.

Laemmli UK (1970) Cleavage of structural proteins during the assembly of the head of bacteriophage T4. Nature 227:680-685.
Lai C-T, Yu PH (1997) $R(-)$-Deprenyl potentiates dopamine-induced cytotoxicity toward catecholaminergic neuroblastoma SH-SY5Y cells. Toxicol Appl Pharmacol 142:186-191.

Liu KP, Gershon MD, Tamir H (1985) Identification purification and characterization of two forms of serotonin binding proteins from rat brain. J Neurochem 44:1289-1301.

Maker HS, Weiss C, Silides DJ, Cohen D (1981) Coupling of dopamine oxidation (monoamine oxidase activity) to glutathione oxidation via the generation of hydrogen peroxide in rat brain homogenates. J Neurochem 36:589-593.

Paz MA, Fluckiger R, Boak A, Kagan HM, Gallop PM (1991) Specific detection of quinoproteins by redox-cycling staining. J Biol Chem 266:689-692.

Pontieri FE, Tanda G, Di Chiara G (1995) Intravenous cocaine, morphine, and amphetamine preferentially increase extracellular dopamine in the "shell" as compared with the "core" of the rat nucleus accumbens. Proc Natl Acad Sci USA 92:12304-12308.

Rosenberg PA (1988) Catecholamine toxicity in cerebral cortex in dissociated cell culture. J Neurosci 8:2887-2894.

Rosengren E, Linder-Eliasson E, Carlsson A (1985) Detection of 5-Scysteinyldopamine in human brain. J Neural Transm 63:247-253.

Schmidt CJ, Wu L, Lovenberg W (1986) Methylenedioxymethamphetamine: a potentially neurotoxic amphetamine analog. Eur J Pharmacol $124: 175-178$

Seiden LS, Sabol KE (1996) Methamphetamine and methylenedioxymethamphetamine neurotoxicity: possible mechanisms of cell destruction. NIDA Res Monogr 163:251-276.

Shen X-M, Dryhurst G (1996) Further insights into the influence of L-cysteine on the oxidation chemistry of dopamine: reaction pathways of potential relevance to Parkinson's disease. Chem Res Toxicol 9:751-763.

Shen X-M, Zhang F, Dryhurst G (1997) Oxidation of dopamine in the presence of cysteine: characterization of new toxic products. Chem Res Toxicol 10:147-155.

Steele TD, McCann UD, Ricaurte GA (1994) 3,4-Methylenedioxymethamphetamine (MDMA, "Ecstasy"): pharmacology and toxicology in animals and humans. Addiction 89:539-551.

Stokes AH, Brown BG, Lee CK, Doolittle DJ, Vrana KE (1996) Tyrosinase enhances the covalent modification of DNA by dopamine. Mol Brain Res 42:167-170.

Stone DM, Stahl DC, Hanson GR, Gibb JW (1986) The effects of 3,4-methylenedioxymethamphetamine (MDMA) and 3,4-methylenedioxyamphetamine (MDA) on monoamine systems in the rat brain. Eur J Pharmacol 128:41-48.

Stone DM, Hanson GR, Gibb JW (1989a) In vitro reactivation of rat cortical tryptophan hydroxylase following in vivo inactivation by methylenedioxymethamphetamine. J Neurochem 53:572-581.

Stone DM, Johnson M, Hanson GR, Gibb JW (1989b) Acute inactivation of tryptophan hydroxylase by amphetamine analogs involves the oxidation of sulfhydryl sites. Eur J Pharmacol 172:93-97.

Tamir H, Huang YL (1974) Binding of serotonin to soluble proteins from synaptosomes. Life Sci 14:83-93.

Terland O, Flatmark T, Tangeras A, Gronberg M (1997) Dopamine oxidation generates an oxidative stress mediated by dopamine semiquinone and unrelated to reactive oxygen species. J Mol Cell Cardiol 29:1731-1738.

Van Iwaarden PR, Driessen AJM, Konings WN (1992) What can we learn from the effects of thiol reagents on transport proteins. Biochim Biophys Acta 1113:161-170.

Velez-Pardo C, Del Rio MJ, Ebinger G, Vauquelin G (1996) Redox cycling activity of monoamine-serotonin binding protein conjugates. Biochem Pharmacol 51:1521-1525.

Whitaker-Azmitia PM, Peroutka SJ (1990) The neuropharmacology of serotonin. Ann NY Acad Sci 600:1-715. 